\title{
Bipolar disorder preceding the onset of multiple sclerosis
}

\author{
Ciro Marangoni ${ }^{1}$, Maria Giulia Nanni ${ }^{1}$, Luigi Grassi ${ }^{1}$, Gianni L. Faedda ${ }^{2,3}$ \\ ${ }^{1}$ Institute of Psychiatry, Department of Biomedical and Specialty Surgical Sciences, University of Ferrara, 44121 Ferrara, Italy. \\ ${ }^{2}$ Lucio Bini Mood Disorders Center, New York, NY 10022, USA. \\ ${ }^{3}$ Child Study Center, New York University Langone Medical Center, New York, NY 10016, USA.
}

\section{A B S T R A C T}

Multiple sclerosis (MS) is the most common inflammatory demyelinating brain disease. The occurrence of psychiatric disorders, especially for major depression, in the course of MS is high. Reports concerning bipolar disorder (BD) remain rather scarce although early descriptions were found in the old neurological literature. The purpose of this article is to provide a critical review of the epidemiology, comorbidity, and treatment findings regarding BD preceding the onset of MS.

Key words: Bipolar disorder, comorbidity, multiple sclerosis, onset

\section{INTRODUCTION}

Multiple sclerosis (MS) is the most common autoimmune disease of the central nervous system associated with inflammatory demyelination. In the United States, the prevalence of MS is $0.1 \%$. MS affects more women than men, with an estimated female-to-male ratio of about 2:1. The median and mean ages of MS onset are 23.5 and 30 years of age, respectively. The peak age of onset is about 5 years earlier for women, but the onset of MS can rarely occur as late as the 7 th decade.

Although the etiology of MS is unknown, the most widely accepted theory is that MS begins as an inflammatory autoimmune disorder mediated by autoreactive lymphocytes. Later, the disease is dominated by microglial activation and chronic neurodegeneration. Inflammation, demyelination, and axon degeneration are the major pathologic mechanisms that cause the clinical manifestations.

Corresponding Author: Dr. Ciro Marangoni,

Institute of Psychiatry, Department of Biomedical and

Specialty Surgical Sciences, University of Ferrara, Corso

Giovecca 203, 44121 Ferrara, Italy.

E-mail: ciromarangoni@hotmail.com

\begin{tabular}{|c|c|}
\hline \multicolumn{2}{|c|}{ Access this article online } \\
\hline Quick Response Code: & \multirow[b]{2}{*}{$\begin{array}{l}\text { Website: } \\
\text { www.nnjournal.net }\end{array}$} \\
\hline & \\
\hline & $\begin{array}{l}\text { DOI: } \\
10.4103 / 2347-8659.167302\end{array}$ \\
\hline
\end{tabular}

Bipolar disorder (BD) is a major psychiatric illness with an estimated lifetime prevalence of $2.1 \%$ among United States adults. In regard to gender, BD type I occurs with equal frequency in both men and women, but BD type II is more common in women, accounting for up to $30-40 \%$ of previously diagnosed unipolar depression..$^{[1]}$ The age of onset of BD is most commonly around 20 years of age (peaking at ages 15-25 years). BD men appear to have 4-5 years earlier onset than BD women. First onset mania is very rare among elderly people.

The pathophysiology of $\mathrm{BD}$ is heterogeneous. Recent scientific findings consider BD as a suite of related neurodevelopmental conditions with interconnected functional abnormalities, early onset, and worsening over time. In addition to accelerating loss of volume in brain regions known to be essential for mood regulation and cognitive function, consistent findings have emerged at a cellular level, providing evidence that BD is reliably associated with dysregulation of glial-neuronal interactions, especially microglia which appear to be overactive. Furthermore, inflammation in the periphery of the body is increased in both depressive and manic phases of the illness, with at least

This is an open access article distributed under the terms of the Creative Commons Attribution-NonCommercial-ShareAlike 3.0 License, which allows others to remix, tweak, and build upon the work non-commercially, as long as the author is credited and the new creations are licensed under the identical terms.

For reprints contact: nn_editor001@nnjournal.net

Cite this article as: Marangoni C, Nanni MG, Grassi L, Faedda GL. Bipolar disorder preceding the onset of multiple sclerosis. Neuroimmunol Neuroinflammation 2015;2:195-9.

Received: 13-03-2015; Accepted: 06-08-2015 
some return to normality in the euthymic state. These findings are consistent with changes in the HPA axis, which are known to drive inflammatory activation. ${ }^{[2]}$

The occurrence of psychiatric disorders in MS was systematically described as early as in 1872 by Charcot. ${ }^{[3]}$ Mental changes in MS included pathological laughing and weeping (pseudobulbar affect), euphoria, mania, depression, anxiety, psychosis, and maladaptive personality changes.

The main body of the literature focuses on the comorbid depression found in MS, whereas reports concerning $\mathrm{BD}$ remains rather scarce although early descriptions of manic episodes in MS were found in the old neurological literature. ${ }^{[4-6]}$

This disproportion reflects the fact that depression is the most frequent among psychiatric disorders in MS, with a lifetime prevalence of $25-50 \%$, a figure two to five times higher than that found in the general population, depending on the country studied. ${ }^{[7]}$

The purpose of this article is to provide a critical review of the epidemiology, comorbidity, and treatment findings regarding $\mathrm{BD}$ preceding the onset of MS.

\section{EPIDEMIOLOGY OF BD IN MS}

Few studies have investigated the prevalence of $\mathrm{BD}$ in patients with MS and vice versa. The first epidemiologic study of this kind, conducted on a large sample (more than 700,000 individuals) in Monroe County (NY), ${ }^{[8]}$ found 10 patients had both MS and BD while epidemiologic data indicated that the expected number of cases would only be 5.4. Joffe et al. ${ }^{\left[{ }^{[9]}\right.}$ conducted a systematic psychiatric evaluation on 100 consecutive MS patients attending a neurology clinic and found a 13\% lifetime prevalence of BD. Fis et al. ${ }^{[10]}$ examined the prevalence of BD among hospital service utilizers in Nova Scotia and compared these measures for the MS and non-MS population. The prevalence of BD in hospitalized MS patients was $1.97 \%$, significantly higher than the $0.92 \%$ for the non-MS hospital utilizers. In a prospective study in 658 consecutive patients with MS attending an outpatient clinic, Edwards, and Constantinescu ${ }^{[11]}$ found that MS population had significantly increased rates of BD compared to the general population (odds ratio $=22.02, P<0.001$ ) Finally, Johansson et al. ${ }^{[12]}$ studied comorbidity between MS and BD in a nationwide cohort. The risk of MS was compared in psychiatric patients and in matched unexposed individuals. The risk of MS was increased in patients with $\mathrm{BD}$ [hazard ratio $(\mathrm{HR})=1.8$, 95\% confidence interval (CI): 1.6-2.2, $P<0.0001$ ] and major depression (HR $=1.9,95 \%$ CI: 1.7-2.0, $P<0.0001$ ) while the risk of MS in schizophrenia was decreased (HR $=0.6$, 95\% CI: 0.4-0.9, $P=0.005$ ).

\section{BD PRECEDING MS' ONSET}

We searched for original articles published in PubMed from inception to 2014 focusing on BD preceding the onset of MS. The search terms used were: (multiple sclerosis) AND (bipolar disorder). All articles identified were English-language, full-text papers. We also searched the reference lists of identified articles for further relevant papers. We selected 16 published articles of case reports where BD preceded the onset of MS [Table 1].

In 26 patients, 20 of which are female, the mean age of onset of BD and MS was 33.42 and 38.46 years, respectively. Nine patients had the onset of BD and MS at the same age. The onset of BD occurred before age 20 years in one patient while 13 patients experienced the onset between age 20 and 29 years, 3 patients between age 30 and 39 years, and 8 patients after age 40 years. The age of onset of MS has a different distribution among these patients: one patient had onset before age 20 years, 6 patients had onset between age 20 and 29 years, 6 patients had onset between age 30 and 39 years and 13 patients had onset after age 40 years.

Twenty-five of these patients were with BD type I (6 with a single manic episode, 6 with recurrent mania, 12 with episodes of both polarity, 1 with rapid cycling) while one had BD type II with rapid cycling. Thirteen patients (4 single manic episode, 3 recurrent mania, and 6 BD type I) had psychotic symptoms in at least one mood episode. Ten patients presented with relapsing/ remitting course of MS, 9 with a progressive course, 4 cases presented with pure psychiatric symptomatology, 3 with other course of MS.

Only 3 cases had a positive family history for MS (cases 1,12 , and 22) whereas 6 patients had a psychiatric family history (cases 12-14-22-26 BD, 16 unknown, 19 unipolar).

Regarding the pharmacological treatment for mood episodes, patients received lithium, antipsychotics, antiepileptics, and antidepressants alone or in various combinations. In terms of treatment response according to psychiatric diagnosis, $60 \%$ of those with single mania, $66 \%$ of those with recurrent mania, $55.5 \%$ of those with BD type I presented full or partial response whereas those with rapid cycling had poorer responses to drugs. No cases of mania were induced by treatments. 


\begin{tabular}{|c|c|c|c|c|c|c|c|c|}
\hline $\begin{array}{l}\text { Case } \\
\text { number }\end{array}$ & Gender & $\begin{array}{l}\text { BD } \\
\text { onset }\end{array}$ & BD type & Treatment; response & $\begin{array}{l}\text { MS } \\
\text { onset }\end{array}$ & $\begin{array}{l}\text { MS presentation and } \\
\text { course }\end{array}$ & Neuroimaging findings & Reference \\
\hline 1 & Male & 58 & $\begin{array}{l}\text { Manic } \\
\text { episode }\end{array}$ & Li; full resolution & 58 & $\begin{array}{l}\text { Progressive spastic and } \\
\text { ataxic quadriparesis }\end{array}$ & NR & [13] \\
\hline 2 & Female & 27 & $\begin{array}{l}\text { Manic } \\
\text { episode }\end{array}$ & NS & 28 & $\mathrm{R} / \mathrm{R}$ cervical cord & $\begin{array}{l}\text { MRI: lesions in centrum } \\
\text { semiovale, periventricular } \\
\text { regions; cerebral and } \\
\text { cerebellar atrophy }\end{array}$ & {$[14]$} \\
\hline 3 & Female & 15 & $\begin{array}{l}\text { Manic } \\
\text { episode }\end{array}$ & APs; full resolution & 15 & $\begin{array}{l}\mathrm{R} / \mathrm{R} \text { neuropsychiatric } \\
\text { symptoms }\end{array}$ & $\begin{array}{l}\text { MRI: diffuse white matter } \\
\text { signal intensity along } \\
\text { ventricles extending to } \\
\text { the centrum semiovale } \\
\text { bilaterally }\end{array}$ & {$[15]$} \\
\hline 4 & Female & 48 & $\begin{array}{l}\text { Manic } \\
\text { episode }\end{array}$ & $\begin{array}{l}\mathrm{Li}+\mathrm{APs} \text {; significant } \\
\text { improvement }\end{array}$ & 48 & $\begin{array}{l}\text { Progressive lethargy, } \\
\text { restlessness, difficulty } \\
\text { concentrating, urinary } \\
\text { incontinence, periodic } \\
\text { disorientation }\end{array}$ & $\begin{array}{l}\text { MRI: lesions in } \\
\text { periventricular and } \\
\text { subcortical areas, corpus } \\
\text { callosum, right } \\
\text { cerebral peduncle, right } \\
\text { brainstem }\end{array}$ & {$[16]$} \\
\hline 5 & Female & 54 & $\begin{array}{l}\text { Manic } \\
\text { episode }\end{array}$ & $\begin{array}{l}\mathrm{AE}+\mathrm{AP} \\
\text { poor response }\end{array}$ & 54 & $\begin{array}{l}\text { Progressive } \\
\text { neuropsychiatric } \\
\text { symptoms and } \\
\text { cognitive impairment }\end{array}$ & $\begin{array}{l}\text { MRI: diffuse and multifocal } \\
\text { lesions in cerebral } \\
\text { hemispheres }\end{array}$ & {$[17]$} \\
\hline 6 & Female & 50 & $\begin{array}{l}\text { Manic } \\
\text { episode }\end{array}$ & AP; poor response & 50 & $\begin{array}{l}\text { Progressive } \\
\text { neuropsychiatric } \\
\text { symptoms and cognitive } \\
\text { impairment }\end{array}$ & $\begin{array}{l}\text { MRI: multiple } \\
\text { punctate and patchy } \\
\text { periventricular lesions, } \\
\text { including Dawson's finger }\end{array}$ & [17] \\
\hline 7 & Male & 20 & $\begin{array}{l}\text { Recurrent } \\
\text { mania }\end{array}$ & $\begin{array}{l}\mathrm{Li}+\mathrm{APs} \text {; full resolution } \\
\text { at } 1 \text { st episode; poor } \\
\text { reponse subsequently }\end{array}$ & 29 & $\begin{array}{l}\text { Progressive unilateral } \\
\text { vision loss, diplopia, } \\
\text { paresthesia, ataxia and } \\
\text { gait difficulties }\end{array}$ & $\begin{array}{l}\mathrm{CT} \text { : diffuse concentric } \\
\text { patchy areas }\end{array}$ & {$[18]$} \\
\hline 8 & Female & 50 & $\begin{array}{l}\text { Recurrent } \\
\text { mania }\end{array}$ & APs; partial response & 56 & $\begin{array}{l}\text { Progressive ataxic } \\
\text { hemiparesis and } \\
\text { cognitive deficits }\end{array}$ & $\begin{array}{l}\text { MRI: lesions in centrum } \\
\text { semiovale, periventricular } \\
\text { regions, thalamus; } \\
\text { marked frontal and } \\
\text { parietal atrophy }\end{array}$ & {$[14]$} \\
\hline 9 & Female & 39 & $\begin{array}{l}\text { Recurrent } \\
\text { mania }\end{array}$ & NS & 41 & $\begin{array}{l}\mathrm{R} / \mathrm{R} \text { brainstem and } \\
\text { thoracic cord }\end{array}$ & NR & {$[14]$} \\
\hline 10 & Female & 21 & $\begin{array}{l}\text { Recurrent } \\
\text { mania }\end{array}$ & NS & 37 & $\begin{array}{l}\text { Progressive } \\
\text { hemiparesis and ataxia }\end{array}$ & $\begin{array}{l}\text { MRI: lesions in centrum } \\
\text { semiovale, periventricular } \\
\text { regions }\end{array}$ & {$[14]$} \\
\hline 11 & Female & 42 & $\begin{array}{l}\text { Recurrent } \\
\text { mania }\end{array}$ & Li + APs; full resolution & 49 & $\begin{array}{l}\text { Arms paraesthesias, } \\
\text { ataxic gait }\end{array}$ & $\begin{array}{l}\text { MRI: multiple hypersignal } \\
\text { lesions in periventricular } \\
\text { area, cerebellum, corpus } \\
\text { callosum, one large and } \\
\text { active lesion on right } \\
\text { frontal lobe with peripheral } \\
\text { oedema; remarkable brain } \\
\text { atrophy }\end{array}$ & [19] \\
\hline 12 & Female & 27 & $\begin{array}{l}\text { Recurrent } \\
\text { mania }\end{array}$ & NS & 43 & $\begin{array}{l}\text { Left lower extremity } \\
\text { weakness and unstable } \\
\text { gait }\end{array}$ & $\begin{array}{l}\text { MRI: lesions in the } \\
\text { periventricular and } \\
\text { subcortical areas, bilateral } \\
\text { centrum semiovale, } \\
\text { right pontine and right } \\
\text { cerebellar cortex }\end{array}$ & [20] \\
\hline 13 & Female & 26 & BD-I RC & $\begin{array}{l}\mathrm{Li}+\mathrm{Aps}+\mathrm{AEs} \\
\text { poor response }\end{array}$ & 29 & $\begin{array}{l}\text { Progressive ataxia, left } \\
\text { hemiparesis, intractable } \\
\text { nausea vomiting, bowel } \\
\text { bladder incontinence, } \\
\text { bilateral Babinski }\end{array}$ & $\begin{array}{l}\text { CT: several enhancing } \\
\text { lesions in left parietal area, } \\
\text { several periventricular } \\
\text { areas of low attenuation }\end{array}$ & [21] \\
\hline 14 & Female & 46 & BD-II RC & $\begin{array}{l}\mathrm{Li}+\mathrm{ADs} \\
\text { poor response }\end{array}$ & 49 & Progressive ataxic gait & CT: normal & [21] \\
\hline 15 & Male & 23 & BD-I & AP; full resolution & 27 & $\begin{array}{l}\text { Progressive ataxic gait, } \\
\text { blurry vision, vertical, } \\
\text { lateral and intermittent } \\
\text { rotary gaze nystagmus }\end{array}$ & CT: normal & [22] \\
\hline 16 & Female & 49 & BD-I & $\begin{array}{l}\mathrm{Li}+\mathrm{APs} \\
\text { poor response }\end{array}$ & 49 & $\begin{array}{l}\mathrm{R} / \mathrm{R} \text { sensory alterations } \\
\text { left leg }\end{array}$ & NR & [22] \\
\hline 17 & Female & 25 & BD-I & $\begin{array}{l}\text { APs + Li; full resolution } \\
\text { at first episode; poor } \\
\text { response subsequently }\end{array}$ & 30 & $\begin{array}{l}\mathrm{R} / \mathrm{R} \text { brainstem and } \\
\text { cervical cord }\end{array}$ & NR & {$[14]$} \\
\hline
\end{tabular}




\begin{tabular}{|c|c|c|c|c|c|c|c|c|}
\hline $\begin{array}{l}\text { Case } \\
\text { number }\end{array}$ & Gender & $\begin{array}{l}\text { BD } \\
\text { onset }\end{array}$ & BD type & Treatment; response & $\begin{array}{l}\text { MS } \\
\text { onset }\end{array}$ & $\begin{array}{l}\text { MS presentation and } \\
\text { course }\end{array}$ & Neuroimaging findings & Reference \\
\hline 18 & Male & 21 & BD-I & $\begin{array}{l}\mathrm{Li}+\mathrm{APs} \\
\text { poor response }\end{array}$ & 31 & $\begin{array}{l}\text { Progressive spastic and } \\
\text { ataxic quadriparesis }\end{array}$ & $\begin{array}{l}\text { MRI: lesions in centrum } \\
\text { semiovale, periventricular } \\
\text { regions, subcortical areas, } \\
\text { thalamus, temporal lobes; } \\
\text { cerebral atrophy }\end{array}$ & [14] \\
\hline 19 & Female & 22 & BD-I & NS & 27 & $\begin{array}{l}\mathrm{R} / \mathrm{R} \text { brainstem and } \\
\text { cervical cord }\end{array}$ & $\begin{array}{l}\text { MRI: three lesions in the } \\
\text { periventricular area of } \\
\text { right hemisphere, one } \\
\text { lesion in the left cerebellar } \\
\text { hemisphere }\end{array}$ & [14] \\
\hline 20 & Female & 33 & BD-I & $\begin{array}{l}\mathrm{Li}+\mathrm{ADs} \\
\text { good response }\end{array}$ & 33 & $\begin{array}{l}\mathrm{R} / \mathrm{R} \text { brainstem, lower } \\
\text { paraparesis, ataxic gait }\end{array}$ & $\begin{array}{l}\text { MRI: periventricular and } \\
\text { temporal horn lesions, one } \\
\text { lesion in the right fronto- } \\
\text { basal region, bilateral } \\
\text { lesions in the splenium of } \\
\text { corpus callosum, corona } \\
\text { radiata, centra semiovalia, } \\
\text { few subcortical lesions; } \\
\text { moderate atrophy in supra- } \\
\text { tentorial compartment and } \\
\text { trunk of corpus callosum }\end{array}$ & [23] \\
\hline 21 & Female & 48 & BD-I & NS & 48 & $\begin{array}{l}\text { R/R neuropsychiatric } \\
\text { symptoms (+ atonic } \\
\text { bladder developed at } \\
\text { age } 81)\end{array}$ & $\begin{array}{l}\text { Neuropathology: small, } \\
\text { atrophic brain; moderate } \\
\text { ventriculomegaly; } \\
\text { numerous lesions in } \\
\text { periventricular location, } \\
\text { right superior frontal } \\
\text { convolution, cingulate } \\
\text { gyrus, centrum semiovale, } \\
\text { corpus callosum, left } \\
\text { cerebellar folia }\end{array}$ & [24] \\
\hline 22 & Male & 20 & BD-I & NS & 40 & $\begin{array}{l}\text { Mild pyramidal signs on } \\
\text { the left side }\end{array}$ & $\begin{array}{l}\text { MRI: lesions in the } \\
\text { periventricular and } \\
\text { subcortical areas, bilateral } \\
\text { centrum semiovale, } \\
\text { corpus callosum }\end{array}$ & [20] \\
\hline 23 & Female & 26 & BD-I & AP; full resolution & 26 & $\mathrm{R} / \mathrm{R}$ brainstem & $\begin{array}{l}\text { MRI: one lesion located } \\
\text { parasagittally within the } \\
\text { left parietal lobe }\end{array}$ & [25] \\
\hline 24 & Female & 39 & BD-I & $\begin{array}{l}A P s+A D \\
\text { full resolution }\end{array}$ & 40 & $\begin{array}{l}\mathrm{R} / \mathrm{R} \text { motor deficit left } \\
\text { side, gait impairment, } \\
\text { urinary incontinence }\end{array}$ & $\begin{array}{l}\text { MRI: lesions in } \\
\text { periventricular area and } \\
\text { cervical cord }\end{array}$ & [26] \\
\hline 25 & Male & 20 & BD-I & Li; poor response & 31 & $\begin{array}{l}\mathrm{R} / \mathrm{R} \text { paresthesia and } \\
\text { weakness left side, } \\
\text { urinary incontinence }\end{array}$ & $\begin{array}{l}\text { MRI: lesions in } \\
\text { periventricular area, } \\
\text { corpus callosum, cervical } \\
\text { spine at C2 and C3 }\end{array}$ & [27] \\
\hline 26 & Female & 20 & BD-I & Li; good response & 32 & $\begin{array}{l}\mathrm{R} / \mathrm{R} \text { quadripyramidal } \\
\text { syndrome with right } \\
\text { kinetic cerebellar } \\
\text { syndrome }\end{array}$ & $\begin{array}{l}\text { MRI: multiple lesions } \\
\text { in periventricular and } \\
\text { semioval areas, cervical } \\
\text { spine at C6 }\end{array}$ & [27] \\
\hline
\end{tabular}

BD: bipolar disorder; MS: multiple sclerosis; Li: lithium; NR: not reported; NS: not specified; R/R: relapsing remitting; MRI: magnetic resonance imaging; AP: antipsychotic; AE: antiepileptics; AD: antidepressant

We did not find any correlation between BD type and MS course type nor between the pattern of white matter lesions and BD type, although lesions were commonly detected in the periventricular and subcortical white matter, the centrum semiovale bilaterally, frontal, parietal and temporal lobes.

\section{CONCLUSION}

The survey of the literature found few epidemiological studies and several case reports of BD clearly preceding MS onset. Based on these data, only limited conclusions can be drawn. In the sample analyzed, the mean ages of onset of both BD and MS were higher than those reported in the literature. Furthermore, the mean difference between BD onset and MS is 5 years although 9 patients (34.6\%) had the onset of BD and MS at the same age. The higher age of onset of MS may indicate that only the form with a later age of onset increases the risk or the co-occurrence/comorbidity with BD.

A high percentage of BD presented with manic episodes (single/recurrent), a finding that may indicated differences between BD occurring in MS patients and those in the general population. Similarly, the higher rate of psychotic features and the low rate of positive 
family history may also indicate differences between $\mathrm{BD}$ in $\mathrm{MS}$ and in the general population.

The available data are insufficient to formulate any hypothesis regarding the etiopathological independence of the two conditions or explain the high rates of co-occurrence and differences in clinical features. In addition, the lack of systematic treatment response data does not permit any comparison between BDs with and without MS. As evidence emerges regarding the inflammatory correlates of both, BD and MS, the value of anti-inflammatory treatments in preventing, delay or ameliorating the course of BD requires further investigations. The limited data on case reports of BD preceding MS yielded several interesting observational findings that might provide information for future research and clinical characterization.

\section{Financial support and sponsorship}

Nil.

\section{Conflicts of interest}

There are no conflicts of interest.

\section{REFERENCES}

1. Angst J, Cui L, Swendsen J, Rothen S, Cravchik A, Kessler RC, Merikangas KR. Major depressive disorder with subthreshold bipolarity in the National Comorbidity Survey Replication. Am J Psychiatry 2010;167:1194-201.

2. Maletic V, Raison C. Integrated neurobiology of bipolar disorder. Front Psychiatry 2014;5:98.

3. Charcot JM. Leçons Sur les Maladies du Système Nerveux. Paris: Delahaye; 1872. (In French)

4. Redlich E, von Economo C. Demonstration mikroskopischer Präparate eines Falles von multipler Sklerose mit psychose. Jahrb f Psychiat 1909;30:315-8. (In German)

5. Euziere J. Les troubles psychiques dans la sclérose en plaques. Arch Gén Méd 1909;3:746-56. (In French)

6. Brown S, Davis TK. The mental symptoms of multiple sclerosis. Arch Neurol Psychiatry 1922;7:629-34.

7. Feinstein A, Magalhaes S, Richard JF, Audet B, Moore C. The link between multiple sclerosis and depression. Nat Rev Neurol 2014;10:507-17.

8. Schiffer RB, Wineman NM, Weitkamp LR. Association between bipolar affective disorder and multiple sclerosis. Am $J$ Psychiatry 1986;143:94-5.

9. Joffe RT, Lippert GP, Gray TA, Sawa G, Horvath Z. Mood disorder and multiple sclerosis. Arch Neurol 1987;44:376-8.

10. Fis KJ, Morehouse SA, Brown MG, Skedgel C, Murray TJ. Hospital-based psychiatric service utilization and morbidity in multiple sclerosis. Can J Neurol Sci 1998;25:230-5.

11. Edwards LJ, Constantinescu CS. A prospective study of conditions associated with multiple sclerosis in a cohort of 658 consecutive outpatients attending a multiple sclerosis clinic. Mult Scler 2004; 10:575-81.

12. Johansson V, Lundholm C, Hillert J, Masterman T, Lichtenstein P, Landen M, Hultman CM. Multiple sclerosis and psychiatric disorders: comorbidity and sibling risk in a nationwide Swedish cohort. Mult Scler 2014;20:1881-91.

13. Solomon JG. Multiple sclerosis masquerading as lithium toxicity. J Nerv Ment Dis 1978;166:663-5.

14. Hutchinson M, Stack J, Buckley P. Bipolar affective disorder prior to the onset of multiple sclerosis. Acta Neurol Scand 1993;88:388-93.

15. Heila H, Turpeinen P, Erkinjuntti T. Case study: mania associated with multiple sclerosis. $J$ Am Acad Child Adolesc Psychiatry 1995;34:1591-5.

16. Young CR, Weiss EL, Bowers MB Jr, Mazure CM. The differential diagnosis of multiple sclerosis and bipolar disorder. J Clin Psychiatry 1997;58:123.

17. Asghar-Ali AA, Taber KH, Hurley RA, Hayman LA. Pure neuropsychiatric presentation of multiple sclerosis. Am J Psychiatry 2004;161:226-31.

18. Peselow ED, Fieve RR, Deutsch SI, Kaufman M. Coexistent manic symptoms and multiple sclerosis. Psychosomatics 1981;22:824-5.

19. Modrego PJ, Ferrandez J. Familial multiple sclerosis with repetitive relapses of manic psychosis in two patients (mother and daughter). Behav Neurol 2000;12:175-9.

20. Kosmidis MH, Bozikas VP, Giannouli V, Karavatos A, Fokas K Familial comorbidity of bipolar disorder and multiple sclerosis: genetic susceptibility, coexistence or causal relationship? Behav Neurol 2012;25:341-9.

21. Kellner CH, Davenport Y, Post RM, Ross RJ. Rapidly cycling bipolar disorder and multiple sclerosis. Am J Psychiatry 1984;141:112-3.

22. Garfield DA. Multiple sclerosis and affective disorder: 2 case reports of mania with psychosis. Psychother Psychosom 1985;44:25-33.

23. Salmaggi A, Eoli M, La Mantia L, Erbetta A. Parallel fluctuations of psychiatric and neurological symptoms in a patient with multiple sclerosis and bipolar affective disorder. Ital J Neurol Sci 1995; 16:551-3.

24. Casanova MF, Kruesi M, Mannheim G. Multiple sclerosis and bipolar disorder: a case report with autopsy findings. JNeuropsychiatry Clin Neurosci 1996;8:206-8.

25. Akkaya C, Kocagoz SZ, Turan OF, Taskapilioglu O, Kirli S. Onset of multiple sclerosis following post-partum depressive and manic episodes. Psychiatry Clin Neurosci 2007;61:698-9.

26. Cerqueira AC, Nardi AE, Souza-Lima F, Godoy-Barreiros JM Bipolar disorder and multiple sclerosis: comorbidity and risk factors. Rev Bras Psiquiatr 2010;32:454-6.

27. Sidhom Y, Ben Djebara M, Hizem Y, Abdelkefi I, Kacem I, Gargouri A, Gouider R. Bipolar disorder and multiple sclerosis: a case series. Behav Neurol 2014;2014:536503. 